This document is the author's version of an accepted manuscript of a published work that appeared in final form in The International Journal of Care and Caring, copyright (C) Policy Press after peer review and technical editing by the publisher. THIS VERSION SHOULD NOT BE CITED. To access the final edited and published work see [https://doi.org/10.1332/239788219X15622471468519].

\title{
The emotional landscape of accessing and navigating formal supports for older adults
}

\section{in one Western Canadian city}

Laura M. Funk1

Wanda Hounslow1

1 Department of Sociology and Criminology, University of Manitoba, Canada

\begin{abstract}
:
Emotions may be pivotal to understanding how fragmented care systems for older adults can generate structural carer burden. Analysing 78 interviews with 32 carers who navigated formal services for an older family member, we distinguish between the emotional experiences of navigation and the emotion work that navigation entails. Emotion work is salient in advocacy situations and when carers seek to maintain relationships with professionals; it is shaped by symbolic and normative understandings of interactions with providers and of 'caring well.' Discussion focuses on how broader contexts shape emotional aspects of system navigation, potentially contributing to carer stress and strain.
\end{abstract}

\section{KEYWORDS:}

Emotion work; family caregiving; system navigation; caregiver strain

\section{Word count:}

8249 
This document is the author's version of an accepted manuscript of a published work that appeared in final form in The International Journal of Care and Caring, copyright (C) Policy Press after peer review and technical editing by the publisher. THIS VERSION SHOULD NOT BE CITED. To access the final edited and published work see [https://doi.org/10.1332/239788219X15622471468519] .

\section{INTRODUCTION}

Providing care for an older family member who becomes ill involves a complex mix of emotions. The academic focus is normally on feelings such as helplessness, guilt, fear, and frustration resulting from carers' interpretations and reactions to stressors such as the illness of the care recipient, their changing relationship, or the caring role and tasks (Anderson et al, 2018; Beeson et al, 2000; Gonyea et al, 2008; Herron et al, 2019; Orgeta and Lo Sterzo, 2013). Yet although carers' emotional experiences are certainly shaped by stressors at individual or dyadic levels, what is less visible is how broader contexts beyond the dyad - such as features of health and social care systems - generate stressors that shape carers' emotional landscapes, and potentially subjective burden. Indeed, dominant conceptualisations of carer stress and burden also tend to focus on individual or dyadic stressors (Purkis and Ceci, 2015). Yet in its broadest definition, carer burden encompasses subjective appraisals of a variety of problems or potential stressors that carers can experience (Chappell and Reid, 2002).

The focus of this article is on carers' emotional reactions to challenges in navigating systems, and how this is complicated further by the emotional context of "feeling rules" (Hochschild, 1979) among carers. More specifically, the purpose is to address a gap in indepth research into carer emotions that explores the complex ways that structural features of formal care systems (ie elements of the organisation of services) for older adults shape carers' emotions as they try to access formal services for their family member. In doing so 
This document is the author's version of an accepted manuscript of a published work that appeared in final form in The International Journal of Care and Caring, copyright (C) Policy Press after peer review and technical editing by the publisher. THIS VERSION SHOULD NOT BE CITED. To access the final edited and published work see [https://doi.org/10.1332/239788219X15622471468519].

we also elaborate a broader vision of the stressors involved in care work, and contribute to a more comprehensive conceptualisation of carer strain or burden.

\section{CARER EMOTIONS, EMOTION WORK AND SYSTEM NAVIGATION}

Family members often engage in considerable navigational work with and for older adults, serving at the interface between informal and formal care. Yet navigating access to and within formal care services appears to be problematic for many older adults and/or carers in countries with complex developed health and social care systems (eg the UK Meyer, 2018; Canada - Funk et al, 2019; New Zealand - Williams et al, 2018; Australia Ballantyne et al, 2005; the US - Martinez-Donate et al., 2013; and Hong Kong - Woo et al, 2013). The navigational work required by carers may be particularly extensive and complex, and more challenging, within fragmented, uncoordinated and increasingly underresourced formal systems (eg Dixon Woods et al, 2006; Funk et al, 2019), as well as in countries expanding direct managed care programmes (Moran et al, 2012; Larkin and Milne, 2014). This is complicated further by substantial variation and complexity in the needs of older adult populations, who may be more likely to have multiple chronic conditions (Ploeg et al, 2017) and to transition between services that vary in structure and delivery (Manderson et al, 2012).

As such, it has been suggested that features of formal care services such as fragmentation, low permeability, complexity, and a lack of transparency about services can contribute to carer strain (Taylor and Quesnel-Vallée, 2016; Funk et al, 2019). In the last 
This document is the author's version of an accepted manuscript of a published work that appeared in final form in The International Journal of Care and Caring, copyright (C) Policy Press after peer review and technical editing by the publisher. THIS VERSION SHOULD NOT BE CITED. To access the final edited and published work see [https://doi.org/10.1332/239788219X15622471468519].

decade scholars have highlighted challenges faced by family carers in administering, navigating and securing formal services for older adults (Funk et al, 2019; Jansen et al, 2015; Meyer, 2018; Peel and Harding, 2014; Ploeg et al, 2017; Williams et al, 2018). Yet within the rich body of literature documenting carers' experiences navigating access to health and social care systems, our review of this literature suggests there is relatively little in-depth exploration of carers' emotions or emotion work during navigation. Certainly, there is a consistent emphasis throughout the literature on carers' frustration with navigation (and interactions with formal providers), and some suggestion that this frustration might be magnified for families who "encounter these challenges repeatedly over time" (Ravenscroft, 2010: 220). Unmet navigation needs and barriers to accessing resources have also been linked within this research to distress (Williams et al, 2018) and isolation (Miller et al, 2009) in carers.

Overall, however, the bulk of the literature on system navigation and access to care tend to focus on task-related care labour (Rosenthal et al, 2007) or on the interactional and temporal processes and strategies involved in navigation (Carpentier and Grenier, 2012; Dixon Woods et al, 2006; Koehn, 2009; Wuest, 2000). More in-depth and sustained attention to the emotions involved in carers' navigational processes and interactions with formal services (Allen, 2000) may provide important insights into stress and strain in unpaid care work.

Reflecting Milligan's (2005) distinction between carers' embodied emotional responses to caregiving, and "the affective, or emotional, entity of informal care work" 
This document is the author's version of an accepted manuscript of a published work that appeared in final form in The International Journal of Care and Caring, copyright (C) Policy Press after peer review and technical editing by the publisher. THIS VERSION SHOULD NOT BE CITED. To access the final edited and published work see [https://doi.org/10.1332/239788219X15622471468519].

(2107), we acknowledge a need to explore not only family carer's emotional responses to subjectively interpreted navigation-related stressors, but also to attend to how the affective complexities of family care work shape the need for emotion work in face to face encounters with representatives of the system being navigated (ie care providers). In other words, carers not only try to cope with the effect of difficult emotions, but in doing so they negotiate (internally and externally in interactions) normative expectations and selfpresentation (Allen, 2000; Ravenscroft, 2010; Shim, 2010). As such, an in-depth exploration of carer emotions during system navigation would also benefit from integrating the concept of emotion work (Hochschild, 1983), which draws attention to how people induce or suppress feelings in line with shared cultural and ideologically prescribed rules. Feeling rules specify the expected type, intensity, direction, and duration of emotions that individuals should feel and experience in particular situations (Hochschild, 1983; Thoits, 1990). Adhering to these rules requires surface acting (regulating one's outward emotional display) and/or deep acting (trying to actually shift one's experience of particular emotions), and can involve strategies such as cognitive reframing and active control of expressive gestures and physiological responses (Hochschild, 1979, 1983; Thoits, 1990).

To date, the concept of emotion work has been applied in research on commodified care work (there known as emotional labour), where health care organisations can influence workers' emotional responses (eg Johnson, 2015; Theodosius, 2006, 2008). Only a few studies have examined family carers' emotion work, usually within interactions with care recipients. Carers strive to invoke positive feelings (Thomas et al, 2002) and to suppress negative feelings such as irritation and frustration (Simpson and Acton, 2013; Herron et al, 
This document is the author's version of an accepted manuscript of a published work that appeared in final form in The International Journal of Care and Caring, copyright (C) Policy Press after peer review and technical editing by the publisher. THIS VERSION SHOULD NOT BE CITED. To access the final edited and published work see [https://doi.org/10.1332/239788219X15622471468519].

2019). When carers are unsuccessful in suppressing negative emotions, this can generate guilt and shame; at the same time, long-term 'success' in doing so could also be damaging (e.g., through dissonance or emotional detachment- Hochschild, 1979). Moreover, as Macrae (1998) highlights, "an important part of the stress of informal car[ing] work lies within the difficult emotion work that care[ers] must perform so that they can view themselves, and be seen by others, as 'good car[ers]' and loving family members" (141).

In sum, we know that family carers, in countries with complex and developed health and social care systems, play an important (and perhaps increasing) role in managerial and navigational aspects of care for older adults. Research suggests navigational work and associated challenges are often difficult for carers, generating frustration, distress and isolation. We also know that the affective dimension of carers' interactions with others are shaped by normative emotional expectations, or feeling rules, that often require them to suppress negative emotions. We know less, however, about the complex ways by which navigation-related stressors produce emotional responses in carers; or how feeling rules shape emotion work in carers' interactions with health care providers. We also know less how these processes shape carer outcomes. The present article draws on qualitative interviews with carers to begin to address these gaps.

\section{STUDY DESCRIPTION, SETTING AND METHODS}

We explored carers' emotional responses and emotion work as they navigate a range of health and social services over time on behalf of an aging family member. We 
This document is the author's version of an accepted manuscript of a published work that appeared in final form in The International Journal of Care and Caring, copyright (C) Policy Press after peer review and technical editing by the publisher. THIS VERSION SHOULD NOT BE CITED. To access the final edited and published work see [https://doi.org/10.1332/239788219X15622471468519] .

conducted an interpretive and thematic analysis of 78 in-depth, semi-structured interviews with 32 family carers of older adults living in or near one Western Canadian city (population size approx. 700,000). In Canada, only medically necessary hospital and physician services have universally guaranteed public funding (and these are privately delivered). Provinces provide varying levels of funding for some home and long-term residential care, with variations in organisation and delivery. In part due to increasing fiscal constraints, attempts to reduce institutional care costs have are believed by some to have generated increased burdens on home and community care services, greater pressures on family members to provide care at home to older adults, and an erosion of social and preventive supports, albeit with provincial variations in the extent of these shifts (Funk, 2013). For instance, erosion may be more pronounced in provinces such as B.C. (Penning et al, 2006), yet provinces such as Manitoba, where the present study was conducted, at the time of data collection still maintained relatively expansive publicly provided home care supports (including light housekeeping). Manitoba also legislated a Caregiver Recognition Act in 2011, though this appears to have had minimal impact on formal services.

Interview data were collected from participants at multiple time points between Oct 2014 and Aug 2016. Following institutional REB approval, a non-random sample of adults in the city providing unpaid support, including help with system navigation, to one or more family members aged 65+ (with age-related mental or physical challenges) was recruited through local media, posters in community centres, and through local carer organisations. 'Family' carer was defined broadly (to include friends or extended family). Three 
This document is the author's version of an accepted manuscript of a published work that appeared in final form in The International Journal of Care and Caring, copyright (C) Policy Press after peer review and technical editing by the publisher. THIS VERSION SHOULD NOT BE CITED. To access the final edited and published work see [https://doi.org/10.1332/239788219X15622471468519].

participants became bereaved between the time we recruited and interviewed them. The other 29 were followed over time for second $(n=29)$ and third $(n=17)$ interviews.

Interviews were conducted by the authors and two research assistants, in participants' homes or another quiet private location (e.g., university office). Questions elicited carers' experiences with, and interpretations of system navigation; the average duration was 73 minutes. Participant characteristics are summarised in Table 1.

\section{***TABLE 1 ABOUT HERE***}

The analytic focus (conducted by both authors) was on exploring participant descriptions about emotions that they - and/or the researchers - interpreted as connected to navigating health and social care systems to access formal help for the older adult. Since interview encounters are social interactions, using an interpretive perspective, we directed analytic attention to how carers attempted, even in the interviews, to convince both themselves and others that they are feeling the 'appropriate' emotions and valued moral identities (Pugh, 2013). Accounts are thus social constructions that in themselves provide insights into the normative emotional expectations associated with family care and system navigation. Analytic steps included re-readings of interviews, thematic coding and constant comparison strategies, and further refining and exploring themes using emotion work (Hoschild, 1979) as an analytic lens. Collaborative analysis was facilitated through inperson analysis meetings.

\section{FINDINGS}


This document is the author's version of an accepted manuscript of a published work that appeared in final form in The International Journal of Care and Caring, copyright (C) Policy Press after peer review and technical editing by the publisher. THIS VERSION SHOULD NOT BE CITED. To access the final edited and published work see [https://doi.org/10.1332/239788219X15622471468519].

Below, we present two closely related but distinct ways in which emotions infuse carers' system navigation work: 1) emotional responses to subjectively interpreted challenges (stressors) when navigating systems; 2) the complex emotion work of navigating systems.

\section{EMOTIONAL RESPONSES TO NAVIGATION-RELATED STRESSORS}

Particularly when they experienced difficulties in securing services, supports or supplies to help their older family member, carers' emotional responses included feelings of: being drained, confused, lost or isolated; frustration, worry, and guilt; and to a lesser extent, dismay or disappointment (i.e., that navigation was so difficult). In terms of intensity, carers' emotions ranged from a vague sense that one might be missing something, to more acute distress. Distressing emotions, especially feeling lost or confused, were more common at earlier stages of caring episodes, or when trying to access information about services believed to be crucial for the care recipient's future well-being. These emotions were exacerbated for some carers when they interpreted formal systems to lack transparency (i.e., something was hidden from them), or when they received conflicting messages from different sources.

For instance, one daughter caring for her mother with dementia expressed considerable confusion about how to access services. At the end of the first interview, the interviewer offers to leave a carer resource guide, and send her some website information on the nursing home waitlisting process. She responds:

"Yeah, because I'm really fuzzy on the whole concept. Because don't you need like a recommendation to get the homecare. So I don't know how you get a 
This document is the author's version of an accepted manuscript of a published work that appeared in final form in The International Journal of Care and Caring, copyright (C) Policy Press after peer review and technical editing by the publisher. THIS VERSION SHOULD NOT BE CITED. To access the final edited and published work see [https://doi.org/10.1332/239788219X15622471468519].

recommendation and then you get the homecare and then you get [waitlisted]. It's like this weird process where like I can't initiate it so... (She is crying) I'm sorry..."

When navigation was interpreted as unsuccessful, some carers also grappled with guilt stemming from feeling like they had been a failure as a carer, as reflected in statements such as "should I have pushed more?" or "I wish I had known sooner." Sometimes this guilt was distinctly related to perceived navigational failings, yet it also may have amplified feelings of guilt about other aspects of the caring experience or relationship with the older adult. One bereaved carer, who had repeatedly attempted to communicate her care concerns to her mother's nursing home staff, believes she did not do enough: "We weren't vocal enough. My mother was in care ....and really we should have done a critical incident [report] and we should have taken them to court at that time and we didn't. So I regret that."

Carers also expressed significant frustration in response to navigation challenges. Earlier on in caring experiences, this included frustration in response to problems in accessing formal resources, including the rigid and constant bureaucratic, administrative and accounting processes often involved. Once services were accessed, carers responded with frustration to the amount of time and energy required to navigate (coordinating, supervising, etc.) the quality, appropriateness or level of formal services (e.g., managerial care, monitoring). Importantly, their frustration was often generalised, meaning that it was directed at 'the system,' although sometimes at particular providers (e.g., gatekeepers). 
This document is the author's version of an accepted manuscript of a published work that appeared in final form in The International Journal of Care and Caring, copyright (C) Policy Press after peer review and technical editing by the publisher. THIS VERSION SHOULD NOT BE CITED. To access the final edited and published work see [https://doi.org/10.1332/239788219X15622471468519].

One daughter who had cared for both parents recounts her frustration with care "administrativia":

"Banking, pensions, income tax, even a simple thing like an address change - you have to have a Power of Attorney. And when you're dealing with the Government - for old age security or pension - you have to have the original or a notarized copy. So all of those things you learn to maneuver, like, who looks after the old age pension? I have no idea. Then you try to figure out - oh that's Public Service Canada. Then you've got to go down there and then they need an original and then you've got to come home. So I was dealing with all of that... all their address changes and pension and - which is a whole other system; even medical benefits and ambulance bills and all the things in my parents' house like hydro and telephone, nobody will talk to you about anything because of privacy [laws]. So it can be extremely frustrating dealing with all of these little I call it administrivia.... But it all takes time."

One daughter with a medical background who was caring for her father in a nursing home believed that ageism makes it difficult to access resources like medications or x-rays. She describes a time that her (father) had a neck issue and she wanted him to have an x-ray to rule out a concussion; this took two weeks of advocating, because the doctor did not see the point of doing one. She adds: "so we finally got an order and I was told that we had to make our own arrangements for private transport to the hospital to get it done..." However, 
This document is the author's version of an accepted manuscript of a published work that appeared in final form in The International Journal of Care and Caring, copyright (C) Policy Press after peer review and technical editing by the publisher. THIS VERSION SHOULD NOT BE CITED. To access the final edited and published work see [https://doi.org/10.1332/239788219X15622471468519].

she learned from a colleague that the nursing home itself should have been handling the arrangements and costs: "I'm familiar with the system and I'm still finding it frustrating that the rules are very different depending on who you talk to."

One daughter caring for her mother describes her frustrations with a primary care centre - the building was physically difficult to access, and although she only wanted her mother to access a family physician, the clinic required repeated, multiple appointments for extensive intake details that she believed were largely irrelevant. She elaborates: "this went on and on like this and I'm sitting there like I've gotta take a whole half morning off work for this, right. And then they wanted her to go twice to see the nurse clinicians for weight and I don't know what all." After she then sought care for her mother from an additional doctor, the clinic said they would close her mother's file, further escalating her frustration:

“...I kind of lost it. I said I've taken her there, like this has taken four hours of my time, for just an intake. I said I don't know how much time you get to take off work to take care of your mother but this is ridiculous. This is a complete waste of my time and taxpayer money. I just... So they don't like me anymore. But it was just so frustrating. It was just crazy."

In another example, a daughter caring for her older mother with mental health/addictions issues describes navigation as generally frustrating and tiring, but could not identify examples. This (and the resigned acceptance it implies) may in part reflect an attempt to brush the frustration away in order to cope: "oh, I know that there has been 
This document is the author's version of an accepted manuscript of a published work that appeared in final form in The International Journal of Care and Caring, copyright (C) Policy Press after peer review and technical editing by the publisher. THIS VERSION SHOULD NOT BE CITED. To access the final edited and published work see [https://doi.org/10.1332/239788219X15622471468519].

[navigation challenges] but I just can't think of those circumstances. Because I've come across that so much and you just kind of have to power through it and find a way right? It's a given." She adds: "nothing comes easily; like it's always a struggle" and describes navigational stress as particularly difficult when she feels responsible - "someone's well being is dependent" on the outcome. In this way, navigational frustration is overlaid with the constant worry or fear that accompanies it.

Another young carer for her grandmother living in a nursing home describes challenges with reimbursements at length (e.g., submitting claims that were not reimbursed, trying to understand medication terminology, etc). Below, she tries to explain her considerable frustration in this regard with reference to her own personal tendency to want clear direction, and her 'nitpicky' approach (implying that in part, she blamed herself for feeling frustrated):

“...that seems so silly but it can be really frustrating when you don't understand it ....but it was a lot of learning curves like that because there's diuretics that aren't accepted and they won't do diuretics and... just weird things like that and I'm getting frustrated. So then being the type of person I am, well, why is this? Oh well, now I understand - putting it on the little checklist. But I'm probably more nitpicky that way but I think it's, I want to try and save her money if I can save her money, right?" 
This document is the author's version of an accepted manuscript of a published work that appeared in final form in The International Journal of Care and Caring, copyright (C) Policy Press after peer review and technical editing by the publisher. THIS VERSION SHOULD NOT BE CITED. To access the final edited and published work see [https://doi.org/10.1332/239788219X15622471468519].

Emotional responses to navigation related-stressors shifted slightly over time as care recipients progressed through formal care systems and as carers learned more about services. Thusly some carers moved from feeling lost or confused, to surprise/shock (at the lack of clarity, barriers to access, etc.), to anger and frustration that, for some, became somewhat muted in the long-term. For instance, referring to system navigation, one daughter notes: "it's hard the first time ,but as the days move on and you get used to the system and then you find the right resources and now it's much better." A few carers also began to simultaneously incorporate positive emotions such as pride or confidence (in their expanded knowledge or skills). Positive emotions did not necessarily, however, reduce resentment and frustration directed towards the system among experienced carers.

\section{THE EMOTION WORK OF SYSTEM NAVIGATION}

After analysing carers' descriptions of emotional responses to navigation-related stressors, we explored how they sought to manage their emotions during navigational work, including invoking or suppressing particular feelings. We focus on this first in relation to more general interactions (with friends, the interviewer, or non-specific others) and then on emotion work in interactions with care providers specifically.

\section{Generalised Emotion Work}

One carer relates a clear example of emotion work when describing her reactions to caring (including but not limited to navigation). She expresses a desire not to become the kind of person who becomes embittered through caring: 
This document is the author's version of an accepted manuscript of a published work that appeared in final form in The International Journal of Care and Caring, copyright (C) Policy Press after peer review and technical editing by the publisher. THIS VERSION SHOULD NOT BE CITED. To access the final edited and published work see [https://doi.org/10.1332/239788219X15622471468519] .

"I don't want to get bitter and I don't want to get angry or frustrated but I've seen it with my aunt because she was a caregiver to my grandparents for 20 years and it made her very bitter and it made her frustrated because my dad wouldn't help and my aunts lived out of Province.”

This participant also describes putting on a face for her friends: "I'll feel angry internally but externally people are like, 'you're just the happiest, most bubbliest, most happiest person I ever did see.' And I'm like [to herself] 'well, on the inside I'm not quite feeling like that.' And I don't know if it's just because I'm that type of person that wants to appear altogether." Along with the frustration of navigation and dealing with less-thanhelpful family members, she feels isolated from her friends who cannot relate, yet does not want to repeatedly respond to their questions about caring because of the complicated emotions it invokes for her. She dons a mask (i.e., surface acting) to deal with this complex mix of emotions when interacting with friends.

This participant's surface acting should be understood in relation to a broader context in which being unable to control frustration can be viewed by others as a failure: revealing frustration (like obligation, or burden: Funk, 2015) may imply they do not love their family member, but it might be viewed as a personal failure to cope effectively. For instance, in an earlier interview, this participant places some responsibility on her aunt for becoming embittered by caring, for "not trying to find a healthy balance" or "going outside the box." Likewise, a bereaved carer echoes the importance of not just expressing frustration through complaining: 
This document is the author's version of an accepted manuscript of a published work that appeared in final form in The International Journal of Care and Caring, copyright (C) Policy Press after peer review and technical editing by the publisher. THIS VERSION SHOULD NOT BE CITED. To access the final edited and published work see [https://doi.org/10.1332/239788219X15622471468519] .

"I'd meet many caregivers [in nursing homes] who would sit there and pardon the expression 'bitch' but wouldn't do anything. I never did that. Well I mean we all bitch but I would always... and I learned this way back when. One of my [work supervisors] said don't come to me with a problem unless you have a proposed solution. So I learned that every time there's a problem there's gotta be a solution. If you don't look for it then nothing is going to change."

In another example, one daughter caring for her coresident mother, who had throughout her interviews shared her frustration with coordinating and managing home care, states at the end of her third interview: "I'm happy that I was part of [the research] because it makes me... So it's like someone is listening to you and you are able to, what do you call that? You are able to.... to whine. (Laughs)" Her appreciation for the confidential nature of the interview reflects her comfort with violating feeling rules and 'venting' her frustrations about caring and system navigation.

Elsewhere, emotion work was more difficult to detect. The boundary between coping strategies and emotion work is often blurred and unclear, and these might represent slightly different analytic lenses. For instance, a carer for her mother living with dementia refers to feeling like a failure whilst navigating the system: "my mother said to me a few weeks ago that she does feel badly about how much time I spend doing her stuff and she only knows a small piece of it. And she looked at me and said it's really too bad because you don't have the personality for this. (Laughs) I suppose I could have been offended by it. I thought it was hysterical. She's absolutely right. I completely don't.” At other points 
This document is the author's version of an accepted manuscript of a published work that appeared in final form in The International Journal of Care and Caring, copyright (C) Policy Press after peer review and technical editing by the publisher. THIS VERSION SHOULD NOT BE CITED. To access the final edited and published work see [https://doi.org/10.1332/239788219X15622471468519] .

in her interview she berated herself for having uncritically accepted information about housing options (which she described as uncharacteristic of herself), yet tries to move on by reminding herself that guilt is not a helpful emotion: "it's not gonna help my mother for me to keep reproaching myself for not having figured it out sooner. And it's not gonna help me." She also tries to mitigate her guilt by focusing on the systemic origins of the challenges she was facing:

"I wasted a lot of time thinking that the problem was my failure to understand the system. I wasted a tremendous amount of time berating myself for not getting it and thinking like you're losing your touch, like how can you not figure this out? Until I finally had a moment when I thought maybe you can't figure it out because it doesn't make sense. Well what a waste of energy that was."

It is analytically challenging to disentangle the extent to which such reframing strategies (blaming the system; dismissing guilt as unhelpful) represent this participants' emotion-focused coping strategies, or her attempts to suppress guilt to align herself with expected feeling rules of being a good carer (e.g., "it's not gonna help my mother"). For instance, presenting oneself as 'wallowing' in guilt may reflect a form of self-centredness that participants sought to avoid in everyday interactions (including the interview).

\section{Interacting with Formal Care Professionals}

During navigational work, carers also don masks to get what they need for their family members when communicating with care professionals. In one example, a young 
This document is the author's version of an accepted manuscript of a published work that appeared in final form in The International Journal of Care and Caring, copyright (C) Policy Press after peer review and technical editing by the publisher. THIS VERSION SHOULD NOT BE CITED. To access the final edited and published work see [https://doi.org/10.1332/239788219X15622471468519] .

carer who liased between her co-resident grandmother and her healthcare provider explains why she was taking this role on, by referring to her mother as unable to control her emotions so as to function as a carer. In contrast, she characterises her own orientation as detached or 'professional,' and implies a need to control any distressing emotions in interactions with professionals and provide care effectively:

"My mom says I have a cold heart but it's not that. I take any feelings that would really bring me down and make this a lot harder and I just kind of put them aside in a box and I close the lid and I don't let them come out because I can't be not $100 \%$ there. Like I can't be crying over something and trying to remember what the doctor is saying to me."

It is important to maintain good relationships with professionals, and this involves containing anger in interactions. A daughter describes her frustrating and conflictual communications with her mother's doctor's office clerk, as well as her efforts to express her frustration "nicely" : “...then very nicely I thanked her for everything. She closed the file and we just left it nice which is what you want anyway, right. But it was a lot of phone calls and stress, too."

As a further example, a woman caring for her coresident father without home supports describes challenges trying to find her father a doctor when he developed cancer. Interactions with professionals were difficult because her father felt vulnerable and misunderstood, and he would get stressed out and angry. Although she was also frustrated 
This document is the author's version of an accepted manuscript of a published work that appeared in final form in The International Journal of Care and Caring, copyright (C) Policy Press after peer review and technical editing by the publisher. THIS VERSION SHOULD NOT BE CITED. To access the final edited and published work see [https://doi.org/10.1332/239788219X15622471468519 ].

with navigational barriers, she was concerned about avoiding conflict and maintaining good relationships with providers:

"And I was kind of upset too because I remember there were roadblocks in the care transitions. And so I don't like conflict so I was trying to work with the system and I know they weren't always pleased with me."

One daughter caring for her father (now in a nursing home), who frequently advised other carers, explains the importance of befriending care staff, and "let[ting] them know that you want to work with them and not against them. And make everything a positive interaction..." Likewise, carers generally characterised themselves as understanding and sympathetic of individual providers. A bereaved carer for both parents, who was also a nurse, describes the poor quality care her father received in hospital, yet tries to be understanding. Her father reacted with yelling when having his underwear changed, and she describes overhearing workers' responses:

"I'm a nurse, I get it, but all I could hear was the frustration in their voices as they were dealing with him. I could hear them and then they were making little jokes about it and everything else. And I was standing outside that door [thinking] this is my dad. And it was funny because when they came out and they saw that I was there I could tell they were horrified because they realized they were rude."

In this situation, the feeling rules of emotional display among paid workers have been violated (resulting in a 'funny' or awkward situation), yet the carer tries not to blame the workers, drawing on her own personal experience in paid care work. For those 
This document is the author's version of an accepted manuscript of a published work that appeared in final form in The International Journal of Care and Caring, copyright (C) Policy Press after peer review and technical editing by the publisher. THIS VERSION SHOULD NOT BE CITED. To access the final edited and published work see [https://doi.org/10.1332/239788219X15622471468519] .

participants without health care backgrounds, a desire not to blame individual providers may reflect their caring identities, norms of interactions with experts, and (as above) attempts to maintain good working relationships with care providers.

Fear of reprisal. Navigational work entailed a complex emotional dynamic wherein carers were aware that if they did not control their frustration in interactions with service providers, this may have a negative impact (physical and emotional) on the care recipient. This layered fear, worry and potential guilt onto frustration. One participant describes the risks if one does not control their emotions when raising concerns about care: "what it does give you is retaliation by the staff [towards their family member] in some circumstances, which is really sad, and that's what families are afraid of." For some carers, fear of reprisal from formal providers (should carers complain or become angry) motivate attempts to go out of their way to establish and maintain good relationships with providers. In some cases, this itself requires emotion work (e.g., suppressing negative emotions or anger) or, more specifically, surface acting. In the following quote, however, a carer indicates that she is trying to contain not only her own, but also her father's own fear about retaliation:

Interviewer: "[after the participant refers to concerns about the lack of accountability for nursing homes] So the recourse for families then is... to go to the media then or something in some cases?" 
This document is the author's version of an accepted manuscript of a published work that appeared in final form in The International Journal of Care and Caring, copyright (C) Policy Press after peer review and technical editing by the publisher. THIS VERSION SHOULD NOT BE CITED. To access the final edited and published work see [https://doi.org/10.1332/239788219X15622471468519] .

Participant: "But again the retaliation threat. And I'll tell you I felt it as well. I didn't act on things because of the concern for retaliation and it is very, very.... My dad will say but don't say anything because you know what I have to work with them and they will treat me terribly. And so we have to respect that."

Becoming angry. Ironically, for carers in certain situations, successful navigation and advocacy was believed to require 'becoming' angry (or at least, displaying anger) in interactions with service providers. A husband caring for his wife with obesity and mobility limitations responds to a question about navigation advice for other carers: "Holler loud and yell. (Laughs) Be a squeaky wheel." For some participants this was difficult emotion work that was challenging to reconcile with their identities as kind and caring persons (or their sympathies for the staff). One granddaughter describes her frustrations with getting her grandmother a prescription for required blood work. After a lack of response to four days of followup phone calls, she became angry with the receptionist and asked to speak with her supervisor: "I got really fed up and 'I don't like doing this, I work in customer service and I don't like being a bitch to other people cause' I'm like 'you know what I don't like it when it happens to me. But at this point I've been calling you guys for three days. You said you'd call me back. You don't call me back'..." She then adds: "I said 'it makes me seem like a bad person because now I've become like an angry person over something; that I'm like this shouldn't have been this complicated at all, right." Narratives such as this reveal that guilt in navigational work may not only stem from times carers 
This document is the author's version of an accepted manuscript of a published work that appeared in final form in The International Journal of Care and Caring, copyright (C) Policy Press after peer review and technical editing by the publisher. THIS VERSION SHOULD NOT BE CITED. To access the final edited and published work see [https://doi.org/10.1332/239788219X15622471468519] .

believe they have 'failed' at system navigation; it can just as easily stem from times in which navigational work requires carers to violate feeling rules.

In contrast, an older carer for her husband with dementia invokes ideas about her age and experience to release herself from the constraints of gendered feeling rules about showing anger. She explains that no longer "takes crap" anymore - describing, in this example, her reaction to a time that someone patted her husband on the head. She states:

"Like, I'm going to be 73 in September. I figure, how many more years have I got? I'm not going to be a doormat. And I know what my rights are. And I'm not going to take it. . That's not my personality from before. I used to, like, somebody'd say something and I'd, like, (timid voice) 'oh, okay,' you know. No, no more. No. No, I've become an advocate for my husband because I feel I have to."

This participant adds that in her family she now has the reputation of being "a bitch," and recounts her frustration dealing with an occupational therapist who ignored her attempts to contextualise her husband's communication challenges and assist him during an assessment, so that (from her perspective) he might most accurately be assessed:

“...but she put her hand like 'this' (stop/blocking) to me. (Angry) And then I just said to her 'you know I have children older than you. I don't appreciate you putting your hand up to me like that.' I said 'I know him and you don't know him' and I 
This document is the author's version of an accepted manuscript of a published work that appeared in final form in The International Journal of Care and Caring, copyright (C) Policy Press after peer review and technical editing by the publisher. THIS VERSION SHOULD NOT BE CITED. To access the final edited and published work see [https://doi.org/10.1332/239788219X15622471468519 ].

said 'I really think that putting your hand up to me, in my face like that, is not very nice and I said I'm offended by that.' She didn't even apologize."

Needing a balance of emotion. Several carers highlighted the importance of a careful balance - to show the right amount of emotion without going too far so as to damage relationships, invoke retribution towards their older family member, or become labelled a problem carer. In the words of one carer: "you have to establish a relationship with them and find out a way of being nice and respectful but getting what you need." In another example, a daughter carer ventures advice for new carers about navigation. Although invoking the feeling rule of "don't take it personally" (suggesting a need for emotional control), and some professional detachment, she entreats carers not to worry too much about offending staff when advocating:

“...everybody sort of has a job in the system to do and that's all there is. It's just a job. So, don't take what they do personally. They just have a job to do. But your job as a caregiver is to advocate for your mom or your dad or whoever it is and that's your job. So take it seriously and do it and don't worry about offending somebody or being angry or whatever because you understand that they have a job to do. They also understand that you have a job to do. So they don't take things personally." 
This document is the author's version of an accepted manuscript of a published work that appeared in final form in The International Journal of Care and Caring, copyright (C) Policy Press after peer review and technical editing by the publisher. THIS VERSION SHOULD NOT BE CITED. To access the final edited and published work see [https://doi.org/10.1332/239788219X15622471468519].

Maintaining a balance is also important in the context of feeling rules and both deep and surface acting. Although anger, invoked for advocacy purposes, can be framed as an expression of love for the care recipient, at the same time any anger expressed about any aspect of the caring experience can be viewed as bounded or restricted by feeling rules about familial love (e.g., despite frustration, "I don't want to wish her away. I'd never do that"). As such, the broader context of emotion work in family caring is implicated even in system navigation, as carers who force themselves to be friendly (controlling frustration and anger) convey both themselves and to providers that they 'want to do' the navigational work (i.e., that they love their family member).

\section{DISCUSSION AND CONCLUSIONS}

The findings of this article contribute to knowledge about family carers' emotions when navigating formal care systems. Carers' self-described emotional responses to navigation related stressors had a temporal dimension in that they shifted slightly over time; moreover, for some carers, both positive and negative feelings about navigation co-existed simultaneously. Perhaps not surprisingly, frustration was the most consistently reported emotional response to navigation challenges (as stressors); interpretations of navigational work and its success or failure also generated particular emotional responses, within a broader emotional landscape of fear and worry for the care recipient. Emotional responses were complicated and shaped by symbolic and normative understandings of interactions with providers, and a desire to be seen by oneself and others as 'caring well.' 
This document is the author's version of an accepted manuscript of a published work that appeared in final form in The International Journal of Care and Caring, copyright (C) Policy Press after peer review and technical editing by the publisher. THIS VERSION SHOULD NOT BE CITED. To access the final edited and published work see [https://doi.org/10.1332/239788219X15622471468519].

Indeed, despite the relatively scant prior attention to emotion work among family carers, we found that emotion work was prominent especially in advocacy scenarios and as carers sought to maintain good relationships with professionals. Although carers generally tried to suppress negative emotions in interactions with others and invoke positive ones, advocating with providers was seen as require invoking just the right amount of anger while still protecting relationships, to avoid reprisal towards the care recipient and to avoid appearing to complain too much. This emotion work is shaped by social norms and symbolic meanings informing face to face interactions between carers and providers (e.g., not being a burden, not challenging professional expertise, etc), and complicated by the internal negotiation of difficult, unclear, and even conflicting moral imperatives surrounding family care and what it means to be a 'good carer' (MacRae, 1998). It is further compounded, for some carers, by the emotional double jeopardy entailed in frustrations emerging from unsupportive interactions with family members and friends (interactions which challenge carers' own expectations of support from these networks).

Through highlighting the (often subtle) presence of emotion work, the present analysis extends understanding of the work involved in providing care, and suggests that emotion work with professionals during system navigation might need to be considered as an important part of the emotion work of caring more broadly (e.g., beyond emotion work within the dyad or with other family). Future research with larger, more representative carer samples could measure long-term outcomes of emotion work for carer well-being outcomes, such as mental health and quality of life. 
This document is the author's version of an accepted manuscript of a published work that appeared in final form in The International Journal of Care and Caring, copyright (C) Policy Press after peer review and technical editing by the publisher. THIS VERSION SHOULD NOT BE CITED. To access the final edited and published work see [https://doi.org/10.1332/239788219X15622471468519].

Our analysis indicates several promising areas for future research. One possibility is to explore the intersection of emotions and carer identity. For example, for some carers self-identification might promote access to and use of services, as well as empower a "sense of belonging and connection to a broader community" (O’Connor, 2007: 165). However, for others, adopting the carer identity (as a master status or primary role) can involve difficult emotions (discomfort, ambivalence), and may entail emotion work, especially for carers who do not wish to self identify (O'Connor, 2007; Molyneaux et al, 2011). At the same time, any resistance to the carer role, even symbolically, might be invoke fear that their family member may miss out on accessing suitable formal care.

Findings from this study provide preliminary support for the conclusion that broader contexts, through emotional processes, indirectly contribute to carer stress and strain. At the very least, the sheer intensity of some carers' emotional distress in this regard suggests that carers' emotional responses to navigating systems be considered a component of the emotional experiences of family caring more broadly (with which they are often closely intertwined). Moreover, the findings of this study highlight how distressing emotional responses to challenging navigation-related stressors are shaped in part by how carers interpret the actions of formal providers as well as their interpretations of the symbolic meanings of their experiences with 'the system' overall. These interpretations deserve greater attention since they may represent an important and often unrecognised source of subjective carer strain. 
This document is the author's version of an accepted manuscript of a published work that appeared in final form in The International Journal of Care and Caring, copyright (C) Policy Press after peer review and technical editing by the publisher. THIS VERSION SHOULD NOT BE CITED. To access the final edited and published work see [https://doi.org/10.1332/239788219X15622471468519].

Future research might extend the qualitative approach used in this article to incorporate navigation-related stressors into models and theories of carer stress, and to assess for statistically significant associations between these stressors, subjective carer and short and long-term well-being outcomes. At a practice level, the assessment of carer needs might also take navigation challenges into account; it is also imperative however to move beyond assessment to address these challenges (e.g., through comprehensive case management or designated family navigator positions).

Carers' emotional responses to navigation stressors are connected to the broader context of the organisation and delivery of care for older adults (Funk et al, 2019). Previous research has provided little in-depth knowledge of how the demands generated within and by formal systems can generate strain for carers; our research suggests emotions may play a key role. Structural changes can make accessing services, supplies and resources more difficult for carers (e.g., through more gatekeeping activity, bureaucratic requirements, narrowing eligibility criteria, heavier staff workloads); these changes, coupled with a "crisis" discourse in relation to formal supports for aging populations, may exacerbate the potential for and intensity of distressing emotional responses when accessing formal supports, as well as heighten carers' sensitivity to feeling rules such as not being a burden on formal systems. At the same time, carers' sense of needing to 'fight' for access may only grow, in such a context; in this way, the demand for emotion work may be increasingly required of carers, yet potentially more complicated, if formal services are difficult to access. 
This document is the author's version of an accepted manuscript of a published work that appeared in final form in The International Journal of Care and Caring, copyright (C) Policy Press after peer review and technical editing by the publisher. THIS VERSION SHOULD NOT BE CITED. To access the final edited and published work see [https://doi.org/10.1332/239788219X15622471468519].

Government efforts to transform health and social care systems should ideally be informed by input from carers' themselves as well as principles of developing carerfriendly (and/or age-friendly) systems (eg the Caregiver Policy Lens - MacCourt and Krawzyk, 2011). Such strategies, alongside the implementation of system navigator supports within publicly funded care services, could help mitigate structural sources of strain for the families whose work collectively supports formal care systems. 
This document is the author's version of an accepted manuscript of a published work that appeared in final form in The International Journal of Care and Caring, copyright (C) Policy Press after peer review and technical editing by the publisher. THIS VERSION SHOULD NOT BE CITED. To access the final edited and published work see [https://doi.org/10.1332/239788219X15622471468519].

\section{REFERENCES}

Allen, D. (2000) 'Negotiating the role of expert carers on an adult hospital ward', Sociology of Health and Illness, 22(2): 149-71.

Anderson, C.G., Linto, J. and Stewart-Wynne, E.G. (2018) 'A population-based assessment of the impact and burden of caregiving for long-term stroke survivors', Stroke, 26(5): 843-9.

Ballantyne, A., Cheek, J., Gillham, D. and Quan, J. (2005) 'Information about the information: Navigating services and supports for older people', Quality in Ageing and Older Adults, 6(3): 17-23.

Beeson, R., Horton-Deutsch, S., Farran, C. and Neundorfer, M. (2000) 'Loneliness and depression in caregivers of persons with Alzheimer's disease or related disorders', Issues in Mental Health Nursing, 21(8): 779-806.

Bookman, A. and Harrington, M. (2007) 'Family caregivers: a shadow workforce in the geriatric health care system?' Journal of Health Politics, Policy and Law, 32(6): 100541.

Brook, P. (2009) 'In critical defence of 'emotional labour': Refuting Bolton's critique of Hochshild's concept', Work, Employment and Society, 23(3): 531-48.

Cain, R., MacLean, M. and Sellick, S. (2004) 'Giving support and getting help: informal caregiver's experiences with palliative care services', Palliative and Supportive Care, 2: 265-72. 
This document is the author's version of an accepted manuscript of a published work that appeared in final form in The International Journal of Care and Caring, copyright (C) Policy Press after peer review and technical editing by the publisher. THIS VERSION SHOULD NOT BE CITED. To access the final edited and published work see [https://doi.org/10.1332/239788219X15622471468519 ].

Carpentier, N. and Grenier, A. (2012) 'The mobilization of outside help by caregivers of persons with Alzheimer's Disease', Qualitative Health Research, 22(10): 1330-44.

Chappell, N. and Reid, R.C. (2002) 'Burden and well-being among caregivers: examining the distinction', The Gerontologist, 42(6): 772-80.

Dixon-Woods, M., Kirk, M. D., Agarwal, M. S., Annandale, E., Arthur, T., Harvey, J., Hsu, R., Katbamna, S., Olsen, R. and Smith, L. (2006) Vulnerable Groups and Access to Health Care: A Critical Interpretive Review. National Co-ordinating Centre for NHS Service Delivery and Organisation, London. Available online at http://www.menshealthforum.org.uk/uploaded_files/SDOvulnerablegroups2005.pdf [Accessed 20 February 2008].

Funk, L.M., Dansereau, L. and Novek, S. (2019) 'Carers as system navigators: Exploring sources, processes and outcomes of structural burden', The Gerontologist, 59(3): 42635 .

Funk, L.M. (2015) 'Constructing the meaning of filial responsibility: Choice and obligation in the accounts of adult children', Families, Relationships, and Societies, 4(3): 383-99.

Funk, L.M. (2013) 'Home health care and family responsibility: A critical discourse analysis of talk and text', Healthcare Policy, 9(Special Issue): 86-97.

Gonyea, J.G., Paris, R. and de Saxe Zerden, L. (2008) 'Adult daughters and aging mothers: The role of guilt in the experience of caregiver burden', Aging and Mental Health, 12(5): 559-67. 
This document is the author's version of an accepted manuscript of a published work that appeared in final form in The International Journal of Care and Caring, copyright (C) Policy Press after peer review and technical editing by the publisher. THIS VERSION SHOULD NOT BE CITED. To access the final edited and published work see [https://doi.org/10.1332/239788219X15622471468519 ].

Herron, R., Funk, L. and Spencer, D. (2019) 'Responding the "wrong way": The emotion work of caring for a family member with dementia.' The Gerontologist. Advance online publication [Retrieved from https://doi.org/10.1093/geront/gnz047].

Hochschild, A. (1983) The Managed Heart: Commercialization of human feeling. Berkeley, CA: University of California Press.

Hochschild, A. (1979) 'Emotion work, feeling rules and social structure', American Journal of Sociology, 85(3): 551-75.

Jansen, L., Forbes, D., Markle-Reid, M., Hawranik, P., Kingston, D., Peacock, S., Henderson, S. and Leipert, B. (2009) 'Formal care providers' perceptions of home- and community-based services; informing dementia care quality', Home Health Care Services Quarterly, 28: 1-23.

Johnson, E.K. (2015) 'The business of care: the moral labour of care workers', Sociology of Health and Illness, 37(1): 112-26.

Koehn, S. (2009) 'Negotiating candidacy: ethnic minority seniors' access to care', Ageing and Society, 29(4): 585-608.

Larkin, M. and Milne, A. (2014) 'Carers and empowerment in the UK: A critical reflection', Social Policy and Society, 13(1): 25-38.

MacCourt, P. and Krawczyk, M. (2011) Supporting the Caregivers of Seniors through Policy: the Caregiver Policy Lens. Vancouver, B.C.: British Columbia Psychogeriatric Association.

Macrae, H. (1998) 'Managing feelings: caregiving as emotion work', Research on Aging, 20(1): 137-60. 
This document is the author's version of an accepted manuscript of a published work that appeared in final form in The International Journal of Care and Caring, copyright (C) Policy Press after peer review and technical editing by the publisher. THIS VERSION SHOULD NOT BE CITED. To access the final edited and published work see [https://doi.org/10.1332/239788219X15622471468519 ].

Martinez-Donate, A.P., Halverson, J., Simon, N.J., Schaaf Strickland, J., Trentham-Dietz, A., Smith, P.D., Linskens, R. and Wang, X. (2013) 'Identifying health literacy and health system navigation needs among rural cancer patients: findings from the Rural Oncology Literacy Enhancement Study', Journal of Cancer Education, 28(3): 573-81. Meyer, K. (2018) 'Carers' experiences of accessing information on supports and services: Learning the social care 'dance', Qualitative Social Work, 17(6): 832-48.

Miller, E.A., Allen, S.M. and Mor, V. (2009) 'Commentary: Navigating the labyrinth of long-term care: shoring up informal caregiving in a home- and community-based world', Journal of Aging and Social Policy, 21: 1-16.

Molyneaux, V., Butchard, S., Simpson, J. and Murray, C. (2011) 'Re-considering the term 'carer': a critique of the universal adoption of the term 'carer', Ageing and Society, 31(3): 422-37.

Moran, N., Arksey, H., Glendinning, C., Jones, K., Netten, A. and Rabiee, P. (2012) 'Personalisation and carers: Whose rights? Whose benefits?', British Journal of Social Work, 42(3): 461-79.

O’Connor, D.L. (2007) 'Self-identifying as a caregiver: Exploring the positioning process', Journal of Aging Studies, 21(2): 165-74.

Orgeta, V. and Lo Sterzo, E. (2013) 'Sense of coherence, burden, and affective symptoms in family carers of people with dementia', International Psychogeriatrics, 25(6): 97380. 
This document is the author's version of an accepted manuscript of a published work that appeared in final form in The International Journal of Care and Caring, copyright (C) Policy Press after peer review and technical editing by the publisher. THIS VERSION SHOULD NOT BE CITED. To access the final edited and published work see [https://doi.org/10.1332/239788219X15622471468519] .

Peel, E. and Harding, R. (2014) “'It's a huge maze, the system, it's a terrible maze":

Dementia carers' constructions of navigating health and social care services', Dementia, 13(5): 642-61.

Penning, M.J., Brackley, M.E. and Allan, D.E. (2006) 'Home care and health reform: changes in home care utilization in one Canadian province, 1990-2000', The Gerontologist, 46(6): 744-58.

Ploeg, J., Matthew-Maich, N., Fraser, K., Dufour, S., McAiney, C., Kaasalainen, S., Markle-Reid, M., Upshur, R., Cleghorn, L. and Emili, A. (2017) 'Managing multiple chronic conditions in the community: A Canadian qualitative study of the experiences of older adults, family caregivers and healthcare providers', BMC Geriatrics, 17: 40.

Pugh, A.J. (2013) 'What good are interviews for thinking about culture? Demystifying interpretive analysis', American Journal of Cultural Sociology, 1: 42-68.

Ravenscroft, E. (2010) 'Navigating the health care system: insights from consumers with multi-morbidity', Journal of Nursing and Healthcare of Chronic Illness, 2(3): 215-24.

Segall A. and Chappell, N. (2000) Health and Health Care in Canada, Toronto, ON: Prentice Hall.

Shim, J.K. (2010) 'Cultural health capital: a theoretical approach to understanding health care interactions and the dynamics of unequal treatment', Journal of Health and Social Behavior, 51(1): 1-15.

Theodosius, C. (2006) 'Recovering emotion from emotion management', Sociology, 40(5): 893-910. 
This document is the author's version of an accepted manuscript of a published work that appeared in final form in The International Journal of Care and Caring, copyright (C) Policy Press after peer review and technical editing by the publisher. THIS VERSION SHOULD NOT BE CITED. To access the final edited and published work see [https://doi.org/10.1332/239788219X15622471468519 ].

Theodosius, C. (2008) Emotional Labour in Health Care: The Unmanaged Heart of Nursing. New York: Routledge.

Thoits, P.A. (1990) 'Emotional deviance: Research agendas', in T.D. Kemper (ed), Research Agendas in the Sociology of Emotions, New York: SUNY Press, pp 180-203.

Thomas, C., Morris, S.M. and Harman, J. C. (2002) 'Companions through cancer: the care given by informal carers in cancer contexts', Social Science and Medicine, 54: 529-44.

Simpson, C., and Acton, G. (2013) 'Emotion work in family caregiving for persons with dementia', Issues in Mental Health Nursing, 34(1): 52-8.

Williams, L.A., Moeke-Maxwell, T., Wiles, J., Black, S., Trussardi, G., Kerse, N. and Gott, M. (2018) 'How family caregivers help older relative navigate statutory services at the end of life: a descriptive qualitative study', Palliative Medicine, 32(6): 1124-32.

Woo, J., Chau, P.H. and Mak, B. (2013) 'Elder-friendly service delivery models', In J. Woo (ed), Aging in Hong Kong: A comparative perspective, New York: Springer, pp 211-34.

Wuest, J. (2000) 'Negotiating with helping systems: an example of grounded theory evolving through emergent fit', Qualitative Health Research, 10(1): 51-70.

\section{FUNDING DETAILS}

This research was supported by an Establishment Grant awarded to Dr. Funk by Research Manitoba (formerly Manitoba Health Research Council).

\section{CONFLICT OF INTEREST STATEMENT}


This document is the author's version of an accepted manuscript of a published work that appeared in final form in The International Journal of Care and Caring, copyright (C) Policy Press after peer review and technical editing by the publisher. THIS VERSION SHOULD NOT BE CITED. To access the final edited and published work see [https://doi.org/10.1332/239788219X15622471468519 ].

The authors declare that there is no conflict of interest.

\section{ACKNOWLEDGEMENTS}

We appreciate the time and insight of all study participants, the journal reviewers, as well as the research support provided by Erin Scott, Sheila Novek, Lisette Dansereau and Catherine Davey. 
This document is the author's version of an accepted manuscript of a published work that appeared in final form in The International Journal of Care and Caring, copyright (C) Policy Press after peer review and technical editing by the publisher. THIS VERSION SHOULD NOT BE CITED. To access the final edited and published work see [https://doi.org/10.1332/239788219X15622471468519 ].

Table 1. Family Carer Participant (n=32) Demographic Information

\begin{tabular}{|c|c|c|}
\hline & & Frequency $(\%)$ \\
\hline \multirow{2}{*}{ Age (years) } & Range & $25-90$ \\
\hline & Average & 57.25 \\
\hline \multirow{2}{*}{ Gender } & Female & $26(81.3 \%)$ \\
\hline & Male & $6(18.8 \%)$ \\
\hline \multirow{4}{*}{ Marital status } & Single/never married & $7(21.9 \%)$ \\
\hline & Widowed & $2(6.3 \%)$ \\
\hline & Separated/divorced & $7(21.9 \%)$ \\
\hline & Married/common-law & $16(50.0 \%)$ \\
\hline \multirow{4}{*}{ Education } & High school or less & $2(6.2 \%)$ \\
\hline & Some university, college & $11(34.4 \%)$ \\
\hline & $\begin{array}{l}\text { or trade school } \\
\text { Undergraduate degree }\end{array}$ & $13(40.6 \%)$ \\
\hline & Post graduate & $6(18.8 \%)$ \\
\hline \multirow{4}{*}{$\begin{array}{l}\text { Employment } \\
\text { status }\end{array}$} & Full time & $17(53.2 \%)$ \\
\hline & Part time/seasonal & $8(25.0 \%)$ \\
\hline & Retired & $4(12.5 \%)$ \\
\hline & $\begin{array}{l}\text { Other (disability, never } \\
\text { participated) }\end{array}$ & $3(9.4 \%)$ \\
\hline \multirow{5}{*}{$\begin{array}{l}\text { Care recipient's } \\
\text { relationship to } \\
\text { carer }\end{array}$} & Mother & $16(50 \%)$ \\
\hline & Father & $7(21.9 \%)$ \\
\hline & Husband & $5(15.6 \%)$ \\
\hline & Wife & $2(6.3 \%)$ \\
\hline & Grandmother & $2(6.3 \%)$ \\
\hline \multirow{3}{*}{$\begin{array}{l}\text { Care recipient's } \\
\text { living situation }\end{array}$} & Co-resident with carer & $17(53.1 \%)$ \\
\hline & Assisted living or $\mathrm{PCH}$ & $12(37.5 \%)$ \\
\hline & Living independently & $3(9.4 \%)$ \\
\hline \multirow{2}{*}{$\begin{array}{l}\text { Visible minority } \\
\text { status }\end{array}$} & Caucasian & $26(81.3 \%)$ \\
\hline & Visible Minority & $6(18.8 \%)$ \\
\hline \multirow{3}{*}{$\begin{array}{l}\text { Average yearly } \\
\text { household income }\end{array}$} & $\$ 39,000$ and under & $6(18.7 \%)$ \\
\hline & $\$ 40,000-\$ 79,000$ & $19(59.4 \%)$ \\
\hline & $\$ 80,000$ and up & $7(21.9 \%)$ \\
\hline $\begin{array}{l}\text { Length of time in } \\
\text { caregiving role }\end{array}$ & $\begin{array}{l}\text { Range } \\
\text { Average }\end{array}$ & $\begin{array}{c}6 \text { months }-30 \text { years } \\
8.45 \text { years }\end{array}$ \\
\hline \multirow{8}{*}{$\begin{array}{l}\text { CR Primary } \\
\text { Diagnosis }\end{array}$} & Dementia & 8 \\
\hline & "Aging" & 5 \\
\hline & Mobility impairment & 4 \\
\hline & Stroke & 4 \\
\hline & Other & 4 \\
\hline & Cancer & 3 \\
\hline & COPD & 2 \\
\hline & Arthritis & 2 \\
\hline
\end{tabular}


This document is the author's version of an accepted manuscript of a published work that appeared in final form in The International Journal of Care and Caring, copyright (C) Policy Press after peer review and technical editing by the publisher. THIS VERSION SHOULD NOT BE CITED. To access the final edited and published work see [https://doi.org/10.1332/239788219X15622471468519 ]. 